\title{
Russian Federation: Report on the Observance of Standards and Codes- Fiscal Transparency Module
}

This Report on the Observance of Standards and Codes on Fiscal Transparency Module for the Russian Federation was prepared by a staff team of the International Monetary Fund as background documentation for the periodic consultation with the member country. It is based on the information available at the time it was completed on August 9, 2004. The views expressed in this document are those of the staff team and do not necessarily reflect the views of the government of the Russian Federation or the Executive Board of the IMF.

The policy of publication of staff reports and other documents by the IMF allows for the deletion of market-sensitive information.

To assist the IMF in evaluating the publication policy, reader comments are invited and may be sent by e-mail to publicationpolicy@imf.org

Copies of this report are available to the public from

International Monetary Fund • Publication Services

700 19th Street, N.W. • Washington, D.C. 20431

Telephone: (202) 6237430 • Telefax: (202) 6237201

E-mail: publications@imf.org •Internet: http://www.imf.org

Price: $\$ 15.00$ a copy

\section{International Monetary Fund \\ Washington, D.C.}





\title{
INTERNATIONAL MONETARY FUND
}

\author{
RUSSIAN FEDERATION
}

\section{Report on the Observance of Standards and Codes (ROSC) Fiscal Transparency Module}

\author{
Prepared by the Fiscal Affairs Department \\ Approved by Michael Deppler and Teresa Ter-Minassian
}

August 9, 2004

\section{EXECUTIVE SUMMARY}

This report provides an assessment of fiscal transparency practices in the Russian Federation in relation to the requirements of the IMF Code of Good Practices on Fiscal Transparency based on discussions with the authorities and other organizations, the authorities' response to the IMF fiscal transparency questionnaire, and other sources of information. The IMF Manual on Fiscal Transparency (http://www.imf.org/external/np/fad/trans/manual/) should be consulted for further explanation of the terms and concepts discussed in this report. This assessment is based on the institutional and legal frameworks at the end of 2003, and does not reflect any changes in 2004. 1/

Russia has achieved considerable progress in fiscal transparency and financial management since 1999, although a number of important reforms remain to be undertaken. The legal framework of the budget and tax system as well as for intergovernmental relations has been reformed. Macroeconomic policy forecasts are soundly based and open for scrutiny. Budget preparation has become sophisticated, with considerable transparency in the process and in the availability of information. The treasury system has strengthened budget execution, control, and monitoring. Reliable data are increasingly available on a timely basis for most levels of general government. Many quasi-fiscal activities (QFAs) have been removed, but some important ones remain. Tax policy has been modernized, and the scope for administrative discretion significantly reduced. A stabilization fund was created as part of the federal budget in January 2004.

The authorities have a clear sense of direction for needed reform, are engaged in a transparent process of developing medium-term plans of action and, in many cases, are already engaged in implementing their plans. The challenges still to be tackled include: narrowing the opaqueness in the boundaries between the general government, the public enterprise sector, and the private sector; addressing remaining weaknesses in intergovernmental relations; assuring the stability of fiscal policies, liberalizing the energy market and reducing QFAs; further strengthening the budget formulation and execution process; and enhancing debt management.

1/ The report does make reference to some plans and actions by the authorities after 2003, but the staff was not in a position to assess the outcomes and implications of these measures. 


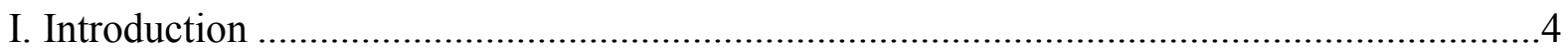

II. Description of Practices ........................................................................................4

A. Clarity of Roles and Responsibilities ............................................................4

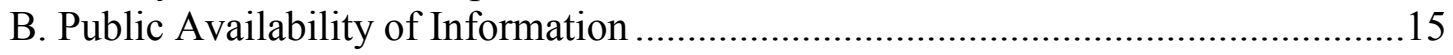

C. Open Budget Preparation, Execution, and Reporting ...........................................19

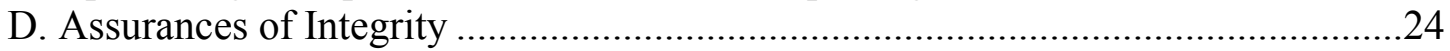

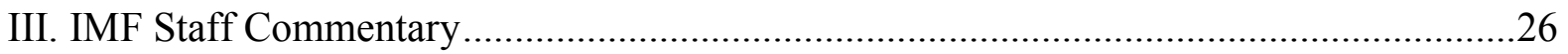

Boxes

Box 1. Efforts to Reduce Quasi-Fiscal Activities in the Energy Sector .................................6

Box 2: Structure of Russia's Intergovernmental Fiscal System ......................................... 12

Box 3: Budget Information of the City of St. Petersburg ................................................ 19

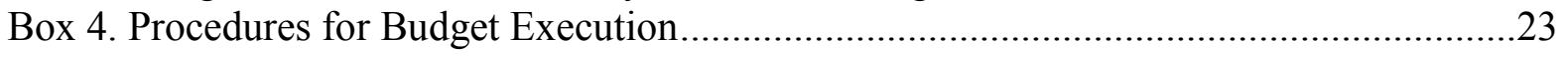

Box 5. The Non-oil Balance ........................................................................................... 30 


\[ \text { ABBREViATiOnS } \]
Central Bank of Russia
Federal Energy Commission
Government Finance Statistics
Federal Treasury Automated System
International Public Sector Accounting Standard
Own resource Accounts of budgetary organizations
Pension Fund
Russian Federation
Quasi-fiscal activities
RAO Unified Energy system
Reports on the Observance of Standards and Codes
Special Data Dissemination Standard
System of National Accounts




\section{INTRODUCTION ${ }^{1}$}

1. This draft report provides an assessment of fiscal transparency practices in the Russian Federation against the requirements of the IMF Code of Good Practices on Fiscal Transparency. The assessment has two parts. The first part is a description of practice, prepared by the IMF staff on the basis of discussions with the authorities and their responses to the fiscal transparency questionnaire, and drawing on other available information. The second part is an IMF staff commentary on fiscal transparency in the Russian Federation.

\section{Description of Practices}

\section{A. Clarity of Roles and Responsibilities}

\section{The definition of general government has yet to fully conform with accepted} international standards. Russian legislation gives no explicit definition of the general government sector (as defined in the Government Finance Statistics Manual 2001 (GFSM2001). ${ }^{2}$ The closest concept defined in legislation is "state bodies." 3 The definition of government is blurred by the significant level of entrepreneurial activities carried out by budgetary organizations, with the revenues and expenditures associated with these activities amounting to some 2.5 percent of GDP. Recent efforts by the Federal Treasury have identified over 31,000 own-resources accounts (ORAs) related to federal budgetary

\footnotetext{
${ }^{1}$ Discussions on fiscal transparency were held in Moscow and St. Petersburg during July 7-18, 2003. The staff team, comprising Messrs. Peter S. Heller, Eivind Tandberg, Dale Chua, and Vincent Moissinac, as well as Mr. Vladimir Drebentsov of the World Bank, met with officials from several federal state bodies, including the Ministry of Finance, the Ministry of Economic Development and Trade, the Central Bank of Russia, the Federal Energy Commission, the Ministry of Energy, the Ministry of Taxes, the Duma, the State Committee on Statistics, the Ministry of Defense, the Ministry for Anti-Monopoly Policy and support of entrepreneurship, the Ministry of Property Relations, and the Customs Committee; as well as, Sberbank, RAO-UES, Gazprom, the Finance Commission of the Administration of St. Petersburg, the St. Petersburg Regional Energy Commission, the Admiralteyski rayon of St. Petersburg, and the State Unitary Heating Enterprise of St. Petersburg, and journalists, a research institute, and investment bankers.

${ }^{2}$ In what follows, the term "general government" relates to the GFSM2001 concept.

${ }^{3}$ The state bodies include the legislative, executive and judicial branches of federal and regional (the 89 "constituent territories of the Federation") government. The definition excludes the three federal extrabudgetary funds, and one principal regional extrabudgetary fund (the "territorial medical funds"). The federal extrabudgetary funds are the Pension Fund, the Social Insurance Fund, and the Medical Insurance Fund. The definition of state bodies also excludes the approximately 12000 local governments. No single document is published that shows an institutional table detailing the structure of government and the rest of the public sector; the authorities have indicated that this information can be obtained from Presidential Decrees and the various legislative acts.
} 
organizations, nearly all of which are now handled through the Treasury system. ${ }^{4}$ There are also over 22,000 government-owned state unitary enterprises and the government holds equity shares in over 6,000 joint stock companies. ${ }^{5}$ Although most of the activities of these entities are commercial in nature, many of them also are involved in government activities, in particular by providing services such as housing or energy at sub-market prices, (and are thus of a quasi-fiscal nature), and these should be assigned to the general government sector. Expenditures funded by entrepreneurial activities of budgetary organizations are not included in the annual budget of the federal government. The accounting and reporting practices of state unitary enterprises are not open to scrutiny by the general public (although the Duma can obtain access). In practice, it is very difficult to distinguish between the assets and liabilities of the state unitary enterprises and those of the government. ${ }^{6}$ Finally, extrabudgetary activities funded by entrepreneurial activities of subnational budgetary organizations are largely not recorded in the subnational budgets. ${ }^{7}$ An expenditure optimizing commission was established in 2003 (headed by the Minister of Finance) to increase the efficiency of budget expenditures, including through a reduction in the number of budgetary organizations. $^{8}$ Its findings were applied in the preparation of the 2004 budget.

3. The energy sector remains the foremost source of quasi-fiscal activities in the Russian economy, despite efforts to improve its regulation, reduce distortions, and rein in such activities (see Box 1). Noncash settlements among RAO-UES and Gazprom have virtually ceased, the freeze on energy prices has been lifted since 1999, the procedures for establishing guaranteed funding have been streamlined, and a strategy for eliminating cross

\footnotetext{
${ }^{4}$ ORAs are sizeable in the education, health, railway, agriculture, defense, and natural resource sectors. Around 50-70 ORAs, mainly in the defense sector, remain outside the treasury system. Although the government is ultimately responsible for the activities of the budgetary organizations, ORAs' liabilities (recognized and contingent) are not monitored and reported.

${ }^{5}$ Of which, about 2,200 as a majority shareholder and about 4,000 in a minority position.

${ }^{6}$ For example, the annual financial accounts of state unitary enterprises are in general not published. In the case of St. Petersburg, the assets that are operated by the state unitary heating enterprise are kept on the books of the city government while some of the liabilities related to its operations are booked with the enterprise.

${ }^{7}$ Very limited data are available at the subnational level. However, the City of St. Petersburg records all entrepreneurial activities of budgetary organizations in its budget.

${ }^{8}$ The main task of the expenditure optimizing commission is to draw up concrete action plans across ministries to support the goal of reducing the size of the government sector in line with the aim to cut the overall tax burden by 1 percentage point per year over the medium term. To this end, the commission aims to cut unproductive and wasteful expenditures, clarify areas of expenditure responsibility for federal and subnational governments, and ensure adequate funding for all remaining expenditure programs. Specific tasks of the commission will include identifying all unfunded mandates and verifying the legal status of (and re-registering) all budgetary units.
} 


\section{Box 1. Efforts to Reduce Quasi-Fiscal Activities in the Energy Sector}

Prior to 1998, the regulated energy sector (RAO UES and Gazprom, in electricity and gas, respectively) constituted the primary source of QFAs in the Russian economy, with implicit energy subsidies possibly reaching 4 percent of GDP in 1995-1997. Significant progress has been achieved in reducing such QFAs and increasing the transparency of the sector's relations with the budget. The most notable changes are as follows:

- non-cash settlement of payments to RAO UES and Gazprom, including through tax offsets, has almost completely ceased to exist; also, the freeze on energy tariff increases, which had been introduced in 1998, was lifted in 1999, and tariffs have been allowed to grow in real terms since 2000;

- the procedures for ensuring budget funding, via budget limits on energy use, by federal budget-financed entities have been streamlined and sufficient funds allocated for these purposes since 2001. Similar policies have been pursued by 69 out of 89 regions. Each year, the increase in energy tariffs has been approved prior to the first reading of the budget, allowing sufficient funds to be budgeted for energy consumption and thus reducing the likelihood of arrears to energy suppliers. However, the data on sub-national budgets' arrears to RAO UES still suggest regional and municipal governments' overdue payables of $\$ 660$ million by mid-2003, including $\$ 420$ million for supplies in 2003; 92 percent of the accumulated debt was at the municipal level.

- the government has authorized the Federal Energy Commission (FEC), which regulates energy tariffs on government's behalf, to prepare a strategy to eliminate fully the tariff cross-subsidization of households by large industrial consumers over the next three years. Under this strategy, regular targeted budget subsidies for poor households will substitute for the current quasi-fiscal subsidies provided to all households. Two accompanying measures will include the elimination of the cross-subsidization of central heating by higher electricity tariffs, and the relatively lower gas tariffs levied on regions more distant from gas production areas;

- a program to reform RAO UES was approved by the Duma in June 2003 and a program relating to Gazprom is under consideration by the government. These reforms target demonopolization of the energy sector by breaking up energy monopolies, and separating out all but the truly natural monopoly segments. By introducing competition into the sector, tariff regulation should be limited only to tariffs on trunk transmission, reducing the potential for quasi-fiscal subsidies embedded in administered prices.

Thus, the most important remaining subsidy relates to energy tariffs set below cost recovery levels (inclusive of reasonable depreciation). The size of this quasi-fiscal subsidy is not easy to assess, reflecting nontransparent estimates by both the government and energy monopolies. Gazprom suggests that its annual losses on the domestic market due to the regulated tariff equals 8.5 billion rubles. World Bank calculations on the basis of long run marginal cost suggest a much higher subsidy - 135 billion rubles a year. RAO UES estimates that the gap between the current electricity tariff $(\$ 0.022 \mathrm{per} \mathrm{KWt} / \mathrm{h}$ on average for all domestic consumers) and the cost of production ( $\$ 0.035$ per KWt $/ \mathrm{h})$ implies an annual subsidy of 345 billion rubles. For Gazprom, the domestic subsidy is financed from export proceeds. Lacking significant export flows, RAO UES can only finance the subsidy by decapitalization, with the company asserting that 70 percent of its fixed assets will exceed the point of a complete physical depreciation over the next 3 to 5 years.

In justifying its policy on tariff caps, the government emphasizes both distributional and macroeconomic considerationsthe impact on inflation and the competitiveness of domestic producers. These must be weighed against the investment needs of the sector. Since 2002, the government has discussed the annual investment programs of RAO UES and Gazprom, although these programs are not published. The FEC has voiced its concerns about the effectiveness of the industry's cost reduction efforts. The FEC is currently working to increase transparency on its tariff-setting methodology, drafting a methodology for calculating a normal return on capital for energy monopolies to be used for setting tariffs in the future. Tariff-setting hearings at the FEC are also open to interested parties. 
subsidies is being prepared. Nevertheless, energy tariffs are still very heavily regulated. Cross-subsidization of tariffs and, more generally, the lack of competition in the energy sector, continue to generate large quasi-fiscal subsidies and impose significant efficiency costs on the economy.

4. Existing legislation provides for a transparent process of privatization. To downsize government involvement in the private sector, a privatization program, ${ }^{9}$ which embodies the principle of presumption of sale, has been adopted. ${ }^{10} \mathrm{~A}$ new procedure has been established under the program ${ }^{11}$ which stresses standardization, openness, and transparency. Auctions will be used more widely and held without reservation prices. In 2003, 630 jointstock companies under federal ownership were sold. In addition in 2003, 571 federal state unitary enterprises were transformed into open join-stock companies, with 100 percent of the shares under federal ownership. For 2004, the government plans to privatize more than 700 companies and transform more than 1000 federal state unitary enterprises into joint-stock companies.

5. The Central Bank of the Russian Federation (CBR) is independent. The Chairman of the CBR board is nominated by the President and appointed by the Duma. The Minister of Finance and the Minister of Economy sit on the CBR board as non-voting members. Other Board members are employees of the CBR. The National Banking Council (NBC) has been established to increase the openness of the CBR. The NBC has 12 members (the Chairman of the CBR, two members from the Federation Council, and three members each from the State Duma, Office of the President of the Russian Federation, and the Russian Federation government). The NBC reviews the annual report of CBR, approves the main expenditure items of the CBR, considers issues related to improvement of the banking sector in the Russian Federation as well as key elements of the unified state monetary policy. Unless otherwise stated in the annual budget law, the CBR is prohibited to lend directly to the central government or to state extrabudgetary funds (CBR law, Article 22). The CBR is barred from buying government securities in the primary market. Lending to federal and

\footnotetext{
${ }^{9}$ The principles and framework are outlined in the Law on Privatization of Federal and Municipal Properties (\#178, December 2000), Presidential decree on the Program of Privatization of State and Municipal Enterprises (\#2284, December 1993), and the Concept Paper on the Implementation of the Privatization Program (\#1024, September 9, 1999).

${ }^{10}$ Under this principle, unless deemed to be of importance to the state, most government share holdings in joint-stock companies will be sold and most state unitary enterprises will be privatized (through direct sale or corporatization).

${ }^{11}$ Government Resolution No. 617, August 17, 2002 stipulates, among others, that the bidding process should be carried out via standard forms; no minimum bids are required; 45 days advance notification must be provided; financial information on assets to be privatized will be made available; and the bids are to be overseen by the Ministry of Federal Properties. It also assures equality of participation in the auction process.
} 
subnational state unitary enterprises is proscribed. No lending at preferential rediscount rates is permitted and lending to financial institutions must be carried out on a uniform basis that is governed by rules. However, the CBR does hold a substantial amount of government debt relating to past fiscal operations; the interest rate paid by the government on some of this debt is unrelated to market conditions. ${ }^{12}$ The CBR is also prohibited by law from charging fees on banking services provided to the government. In return, CBR does not pay interest on the balances of budget funds. ${ }^{13}$ (not a statutory restriction).

\section{Government interference in the operations of public financial institutions also} appears to be generally limited. Sberbank, the country's largest financial institution providing credit, indicates that it conducts its operations in an arms-length manner, without government interference. However, the government provides a full guarantee for household deposits in Sberbank. While rates of credits from the Sberbank are among the lowest, the bank is able to attract deposits at rates that do not fall below the average rates of the banking system. The government plans to eliminate the state guarantee to Sberbank by 2007. The government is represented on the Supervisory board of Sberbank by three senior officials from the Ministry of Finance (including the Minister) and one from the Ministry of Economic development and trade. ${ }^{14}$ As to financial institutions owned by subnational governments, these are prohibited from providing subsidized lending. However, such activities are known to have taken place, although they are not likely to be large in macroeconomic terms.

\section{Regulation of private enterprises is fairly complex and the need for} strengthening and simplification is acknowledged. The basic laws governing business activities are set out in the Civil Code, the special federal law for joint-stock companies ${ }^{15}$, and the special federal law for private limited companies ${ }^{16}$. Government resolutions, guided by the three basic laws, lay down the rules and guidelines covering the general areas of establishment, conduct, and operations of businesses. Some regulatory functions are carried out in the government, through ministries and departments or by special federal regulatory

\footnotetext{
${ }^{12}$ However, in February 2003, with the authority granted by Article 134 of the 2003 Federal Budget law, the Ministry of Finance converted most of the permanent coupon-income federal loan bonds from the CBR into consolidated federal bonds, with market rates. This conversion enabled the CBR to lengthen the list of investment operations on the open market within the framework of monetary policy.

${ }^{13}$ By law, balances of budget funds are to be placed at the CBR.

${ }^{14}$ The Board, which is chaired by the Chairman of the CBR, also includes six representatives of the CBR, four senior managers of Sberbank, and two representatives of minority shareholders.

${ }^{15}$ Federal law No. 208 of December 26, 1995, “On joint-stock companies.”

${ }^{16}$ Federal law No N 14 FZ of February 8,1998 “On limited liability societies (companies)”
} 
commissions (for example, the Federal Commission on Stock Markets on financial market activities, and the Federal Energy Commission on energy pricing). According to the Ministry of Economic Development and Trade, in certain areas regulations are overly complicated (for instance, regarding the information requirements for the issuance of equity financing) or are in conflict (for example, concerning licensing as governed by the Security Law and the Law on Licensing). In addition, gaps are evident in the regulatory framework in some areas (for example, concerning minority shareholders' rights, business reorganization, bankruptcy, and takeovers).

8. Government equity holdings are not identified in budget documentation. The government is not required by law to make public the annual financial and balance sheet information of state unitary enterprises or its holdings in joint stock companies. The Ministry of Property Relations manages a federal property register, which is routinely updated to reflect the ongoing privatization program. The register does not include subnational governments' equity holdings nor assets of budgetary organizations providing entrepreneurial activities; a master list of all equity holdings of the general government is not maintained. The draft privatization program for the coming fiscal year is submitted to the Duma together with the draft budget law. As part of the privatization program, detailed financial information on federal state unitary enterprises slated for privatization is published on the Ministry of Property Relations website (http://www.mgi.ru/). All federal state unitary enterprises are required to submit quarterly reports to their respective state bodies and to the Ministry of Property Relations. Only large state unitary enterprises are required to be externally audited once a year.

9. Intergovernmental fiscal relations are defined in the law but has lacked stable rules for expenditure and revenue assignments. Russia is a three-tiered federal state consisting of 89 regions and 11,566 local self-governments within these regions (as of April 1, 2003). Federal laws ${ }^{17}$ have established expenditure mandates and revenue sources for each level of government (see Box 2). ${ }^{18}$ Legislative reforms have recently been passed to organize fiscal decentralization more coherently.

10. The demarcation of expenditure mandates is being improved. Until 2004, the clarity of expenditure mandates was hampered by the presence of unfunded mandatory expenditures, a lack of clear separation of roles in areas of shared responsibility, and a lack of expenditure autonomy of subnational governments. This led to situations where local selfgovernment often had to assume expenditure responsibilities delegated from the federal and regional governments without adequate financing and on the basis of budgetary standards

\footnotetext{
${ }^{17}$ These fiscal relationships are governed by the Tax Code, the Budget Code, the federal law on the principles of organization of regional governments, and the federal law on principles of organization of local self-governments.

${ }^{18}$ Statistics as of April 1, 2003.
} 
and practices established by the latter. ${ }^{19}$ The most significant unfunded mandates were social entitlements established by federal and regional laws, including subsidized housing and communal services to the veterans and the disabled. ${ }^{20}$ Legislative reforms have recently been passed that rationalize expenditure mandates. The new legislation ${ }^{21}$ aims at strengthening the budgetary autonomy of subnational governments and the transparency of their budgets. Starting in 2004, subnational governments have been granted more independence to implement their expenditure responsibilities, which should help realize their constitutional rights and increase their accountability to the local population. For instance, wage policies, previously conducted based on federal standards, have been devolved, with the safeguard that subnational governments receiving equalization transfers are prohibited from paying wages higher than comparable federal wages. At the same time, fiscal transparency is to be improved at the subnational level, through stricter budget reporting standards and the generalization of rule-based intergovernmental transfers (see below) The intention of the reform is also to rationalize the allocation of expenditure mandates by narrowing shared responsibilities, shifting back significant responsibilities from local to upper government levels, and eliminating unfunded social mandates. The authorities reported that a significant rebalancing had been achieved by the new legislation and in the 2004 budget.

\section{However, the coherence of expenditure mandates requires continued attention.}

The extent to which recent reforms have resolved imbalances between fiscal resources and responsibilities for subnational governments is unclear as of yet and will need to be assessed critically. In particular, local self-governments may still experience difficulties to fulfill their fiscal responsibilities due to the burden created by a largely inefficient housing and communal services sector. In many regions, local budgets continue to use a large share of their budget resources to finance price subsidies for households, which has crowded out other social expenditure. Moreover, risks of soft budget constraints and fragmentation of the budget system are significant as a result of fiscal devolution. The management of these risks may also be complicated by plans to introduce a fourth tier of government for the purpose of budgeting.

19 These included federal regulations and norms on the number and types of budgetary organizations, civil servants, civil service wages, and some minimum expenditure requirements.

${ }^{20}$ The cost of federal unfunded mandates was estimated by the Ministry of Finance at 8 percent of GDP in 2003, taking account that the 2003 budget temporarily suspended some of these mandates. If fully met, the costs of unfunded mandates would have amounted to about 19 percent of GDP.

${ }^{21}$ Amendments to the law "on the general principles of the organization of the legislative and executive government authorities of constituent territories of the Russian Federation" were enacted on July, 4 2003. The framework of these reforms is outlined in Resolution \#584 of the government of the Russian Federation "on a Program for the Development of Budgetary Federalism in the Russian Federation." 
12. Revenue assignments need to be stabilized. Tax arrangements between the three tiers of government have been improved by transferring the personal income tax to the subnational budgets and reallocating the VAT to the federal budget. However, the current tax-sharing arrangements have changed frequently in recent years, reflecting the ongoing tax reform. Some of these arrangements appear to be renegotiated every year between the three tiers of government in this context, including the profit tax and excise taxes. This continues to undermine the ability of subnational governments to formulate medium-term financial plans. Another weakness of the structural reliance, in the intergovernmental system, on shared tax bases has been the incentive that it has given some subnational governments to mobilize additional resources from local enterprises in a way that bypasses tax sharing; in the past, noncash tax offsets were used, ${ }^{22}$ but recently such practices have been radically reduced. According to the authorities, noncash offsets were fully eliminated at the federal level (in 1998) and for regions recipient of federal transfers (in 2003). ${ }^{23}$

\section{The system of federal transfers to regions is operated transparently and is being replicated by a growing number of regions in their relationships with local}

governments. Federal current transfers are based on a formula-based assessment of regions' relative fiscal capacities, capturing their revenue base and current expenditure needs. Capital transfers are also allocated based on equalization objectives. Special federal transfers, such as for the co-financing of social programs, are conditional on the undertaking of structural reforms (e.g., communal service sector reform). The implementation of this system is discussed annually by a tri-partite commission comprised of members of the government and the two chambers of the Federal Assembly; the commission meets before each annual budget submission. This system is complemented by strict rules for subnational deficits, borrowing, and debt (see section C). However, the system is undermined by the frequent extension of inter-budgetary loans that are rolled over for several years, in breach of the Budget Code. Until 2004, regional transfers to local governments remained highly discretionary, except in a few regions that had opted for formula-based approaches. Starting in 2004, legislative reforms aim to expand the federal transfer model to the regional level-however the extent to which this has been done in the 2004 regional budgets is yet unclear.

\footnotetext{
${ }^{22}$ Non-cash tax offsets are ad-hoc agreements between the tax authority and one or more taxpayers to mutually nullify tax liabilities against budget payments without cash settlement. Non-cash payments are nontransparent because they are generally not reflected in the treasury records and can imply significant quasi-fiscal losses.

${ }^{23}$ More generally, the sharing of tax bases is less transparent than exclusive tax assignments because it makes it more difficult for taxpayers to perceive the level of tax burdens.
} 
Box 2: Structure of Russia's Intergovernmental Fiscal System

Three levels of government are endowed with budgetary powers in Russia: the federal government and regional governments, which together constitute the Russian Federation, and local self-governments. Regional governments have varying descriptions, including region (oblast and krai), autonomous region, republic, ethnic republic, autonomous republic, autonomous district (okrug), federal city, and territory. The basis for distinction was the nationality-based logic of the 1978 Constitution. The existing legislation allows local communities to constitute local self-governments using various territorial and organizational forms. This third layer comprises cities, and city or rural settlement, district, and rayons.

Asymmetry in regional-federal fiscal relations was eliminated in principle by the 1993 Constitution and the 2000 Budget Code. The Constitution declared all regional governments or "constituents of the Federation" equal, with the same rights and obligations vis-à-vis the Federation. In particular, regional governments have the right to develop their own legal systems, including passing their own charter, or constitution in the case of ethnic republic, and electing their own heads of government. Remaining legal ambiguities ${ }^{24}$ were addressed in the 2000 Budget Code, which explicitly prohibited against bilateral fiscal arrangements between the federal and regional governments (Article 132).

The legal budget framework ${ }^{25}$ formally assigns the major expenditure responsibilities between levels of government. With some exceptions, these assignments broadly reflect the principles of subsidiarity and correspond with benefits areas. Public services with implications for the entire nation, such as defense or the judiciary, are assigned to the federal level; public services with benefits spreading across communities in a region, such as specialized hospitals, are the responsibility of oblasts; and services affecting mainly the residents of separate communities, including road construction or garbage collection, should be supplied by local self-governments. Exceptions to these assignment principles have appeared in areas where there are overlapping responsibilities, such as social protection, the financing of certain health institutions, and public investments. Federal social entitlements have also often been transferred to lower government levels.

Tax reforms since 2000 changed the structure of revenue assignments, with the result of shifting significant tax revenue from subnational budgets to the federal budget. At present, the entire revenue of the VAT and excise taxes on mineral raw materials, and 70 to 80 percent of taxes on the extraction of economic minerals are assigned to the federal budget. The personal income tax is assigned to subnational budgets in full, with the provision that at least 50 percent should be transferred to local self-governments. Other taxes, including the profit tax and some excise taxes, continue to be shared on a yearly basis. Changes in these tax shares continue to follow a "regulation" approach, aimed at equalizing governments' revenue inflows with their expenditure needs, particularly between regions and local governments.

There are five main categories of federal transfers to regional budgets, the distribution of which is regulated in the Budget Code. Equalization transfers are computed according to a methodology that minimizes the variance of the budget capacity among regions. They are linked to special conditions ensuring fiscal discipline, such as using the federal treasury for budget execution. Transfers for the financing of infrastructure projects apt to reduce socio-economic disparities between regions are appropriated in the federal budget. Special transfers are provided to compensate subnational governments for social entitlements such as child allowances and in-kind benefits for the disabled (e.g. free housing and communal services). These transfers do not however provide for several other federal social benefits, which have remained largely unfunded. Another category of transfers is aimed to co-finance housing and communal service subsidies for low-income families (about 25 percent of the total cost). Finally, a transfer scheme has been developed, with IBRD financing, to reward regions that undertake fiscal reforms.

Source: Partly based on work by E. Dabla-Norris, J Martinez-Vasquez, and J Norregard on fiscal decentralization in former FSU countries

\footnotetext{
${ }^{24}$ The Constitution allowed the federal authorities to enter into bilateral arrangements with particular regions. These agreements could cover budgetary relations until 2000.

${ }^{25}$ The 2000 Budget Code, a law "On General Principles for the Organization of Legislative (Representative) and Executive Government Authorities of Constituent Territories of the Russian Federation (No. 95-FZ of July 4,2003 ) and a number of sectoral laws (e.g., for health, education, and social assistance)
} 
14. The roles of the different branches of the state are clearly defined in the constitution. State authority is exercised by the President, the Federal Assembly, the government of the Russian Federation and the courts of the Russian Federation ${ }^{26}$ The chairman of the government (who has powers equivalent to a prime minister) is appointed by the President with the consent of the State Duma. The Federal Assembly (the State Parliament) has two chambers, the Duma (lower chamber) and the Federation Council (upper chamber). The judicial branch consists of three court systems; an arbitrate court system, a general jurisdictional (federal) court system, and the constitutional court. The Duma may approve or reject the government's budget proposals as submitted in the draft annual budget law, but it cannot change the aggregate levels of revenues and expenditures submitted without the government's concurrence. The government can be sued in courts by legal entities; cases on economic matters are heard in the arbitrate court system.

\section{Principles on fiscal management are elaborated in detail in the Budget Code, ${ }^{27}$} which is generally consistent, although some internal ambiguities and elements could deter progress towards greater transparency. The Code explicitly embraces the principle of openness, mandating the publication of approved budget and budget execution reports and of making information available to the legislative bodies at all levels of governments (Article 36). An extensive set of documents must accompany the draft budget (Article 192). The Code also requires the draft budgets of the federal extrabudgetary funds (administered outside the federal budget) to be presented together with the draft annual budget law, and requires reports on execution to be submitted to the Federal Assembly. However, some internal inconsistencies in the Budget Code have led to ambiguity on the intended legal requirement regarding the recording of revenues from entrepreneurial activities of budgetary organizations. Specifically, Article 41.4 defines non-tax revenues to include revenues from the use of assets under state or municipal ownership. This article, however, appears to be inconsistent with Article 161.6, ${ }^{28}$ which is widely interpreted as providing legal authority for

\footnotetext{
${ }^{26}$ The term "federal government" refers to the central government; in addition, the term also refers to the name of the decision-making body of the central government which in other countries might be termed the Cabinet or Council of Ministers.

${ }^{27}$ Budget Code of the Russian Federation (No. 145-FZ, July 1998) and subsequent amendments and additions. The Budget Code came into force in 2000. It sets out the general provisions of budget legislation; defines the jurisdiction of the federal and subnational governments on budget relations; creates a framework for expenditure management; lays down rules on national debt; and establishes a fiscal rule for the subnational governments. In addition, a very detailed budgetary process is laid out in the Code.

${ }^{28}$ In essence, this article states that the chief manager of a budget resource shall, together with the Federal Treasury, define the right of a state-financed institution to redistribute expenditures independently from resources received from extra-budgetary sources.
} 
revenues from entrepreneurial activities of budgetary organizations to be kept off-budget (rather than transferred to the federal budget as non-tax revenues). Legal opinions on sectoral laws (including, for example, in the education and transportation sectors) are supportive of this interpretation. ${ }^{29}$ In addition, the Code contains some elements of central planning, using norms as the basis for the costing of government services (Article 177). Often, the standards of service set by such norms are not attainable with available resources, and their legal status potentially encourages unaffordable budget commitments. Long-term earmarked programs (Article 179) could lead to similar problems.

16. The legislative basis for taxation and customs policy is reasonably transparent, but minor ambiguities and some conflicts in tax laws remain. Part I of the new Tax Code adopted in 1999 includes definitions, administrative provisions, and general provisions. Part I regulates the rights and responsibilities of taxpayers and authorities, and has been amended several times. Some amendments developed to iron out technical wrinkles between Part I and the Foundation Law of the Russian Tax System, however, have not yet passed. ${ }^{30}$ Part I of the Tax Code significantly reduces the use of discretion in tax administration; tax offsets and netting operations are now prohibited. Part I also provides clear assurances that "all irremovable doubts, contradictions, and ambiguities of legislative acts relevant to taxes and fees shall be interpreted in favor of taxpayers" (Article 3.7). ${ }^{31}$ Part II of the Tax Code contains several chapters adopted in recent years, including the VAT, Personal Income Tax, excises, and the Unified Social Tax, Profit Tax, and the Mineral Resource Tax. In general, exemptions have been widely curtailed; perhaps most substantially in the new profit tax adopted in 2002. Although two federal laws on special zones for Kalingrad Oblast and Magadan provide preferential treatments to businesses and grant tax concessions, annual

\footnotetext{
${ }^{29}$ On this basis, state bodies have protested against the requirement that their ORAs be handled through the Treasury and made to meet the reporting requirements. A recent verdict in a lawsuit by several education institutions ended in a compromise decision by the court: budget entities have to open their ORAs in the Treasury and report on these activities, but the Ministry of Finance cannot require a specific share of the ORA revenues to be transferred to the budget. The Ministry of Finance has disputed this interpretation of the law, and plans to contest it aggressively in the court system. It is also preparing legal amendments to the Budget Code to clarify the legal situation.

${ }^{30}$ For example, some natural resource revenues are classified as taxes in Part I but as nontax revenues in the Foundation Law. Separately, the adoption of an optional simplified tax (a small business tax) in 2003 , led to a conflict with the mandatory imputed income tax for certain economic activities. Specifically, when a legal entity is involved in a range of businesses and if a specific part of that business happens to fall under the ambit of the imputed tax, the legal entity cannot opt to be taxed under the simplified tax (even if it meets the conditions set out under this tax). This conflict was resolved in July 2003 when a new law was passed allowing the co-existence of these taxes, provided the legal entity keeps separate accounts; one for those activities that are subject to the imputed tax and one for those to be taxed under the small business tax.

${ }^{31}$ Article 3.7 may need to be revised to rebalance the rights of taxpayers and tax officials.
} 
budget laws regularly suspend such concessions except with respect to the customs tariff. ${ }^{32}$ A new Custom Code ${ }^{33}$ was adopted earlier this year, which seeks to clarify the rights and responsibilities of traders and customs officers, and significantly lessen the scope for discretion in customs valuation. Steps have been taken to automate customs procedures and to standardize documentation requirements and settlement procedures for late payments. No exemptions are provided under the Customs Code. In sum, these measures present a major step in furthering transparency in the customs service, which has generally been perceived by the trading community as a source of governance difficulties. Uniform application of the Customs Code over the entire country will be a challenge, particularly, as geography could have an impact on customs administration.

17. Public servants are subject to a code of behavior. A public service law ${ }^{34}$ and a Presidential decree ${ }^{35}$ frame a code of conduct for all public servants, which spells out their rights and responsibilities. Public servants are required to declare annually their holding of assets and liabilities to the tax authorities. Complementary legislation has been passed to assist in the combating of corrupt practices. The business community and the general public continue to perceive the level of governance problems in their dealings with some branches of the government to be quite high, and it is clear that effective implementation of the code of behavior has yet to be achieved. ${ }^{36}$

\section{B. Public Availability of Information}

\section{The federal budget of the Russian Federation presents the fiscal activities of the} federal government excluding federal extrabudgetary funds. Separate budgets of federal

32 The concessions that remain relate to customs duties on imported goods coming into these areas, providing there are no re-exports to the rest of Russia or that there is at least 30 percent value added provided by enterprises within the zone. These concessions do not apply however to excisable goods.

${ }^{33}$ The Customs Code (which contains 460 chapters) was developed under WTO principles. According to the Customs Committee, it is compatible with the customs law of the European Union, Russia's largest trading partner.

${ }^{34}$ Federal law No. 119-FZ, July 31, 1995, "On the Fundamentals of Public Service in Russian Federation."

${ }^{35}$ Presidential decree No. 885, August 12, 2002, "On the Approval of General Principles of Official Behavior for Public Servants."

${ }^{36}$ A recent survey of 21 leading exporter countries sought to gauge the propensity of local companies to pay bribes to public officials. Russia scored at the bottom (3.2 out of 10, where 10 represents no corruption). Australia scored at the top (8.5), United Kingdom (7.9), Malaysia (4.3), Italy (4.1), and China (3.5); see Transparency International Bribe Payer Index, May 2002 (Berlin). 
extrabudgetary funds are made publicly available but provide information which is not fully classified. ${ }^{37}$ The budget does not cover entrepreneurial activities of budget entities. The budget provides aggregated expenditure allocations for national defense, law enforcement, and national security. The details of some of these expenditures are contained in secret supplements to the budget. This information is accessible outside the government only to the chairmen of the upper and lower chambers and to the concerned special committees of the Duma. The budget specifies all federal transfers to lower levels of government and separates clearly earmarked budget funds. The budget document provides indicative data on the consolidated budget (estimates and outcomes) of most general government (except the territorial medical funds).

19. The budget documents provide estimates of the expected budget outturn for the year preceding the budget and summary budget forecasts for the two years following the budget. Budget estimates are based on two macroeconomic scenarios that are formulated in the government's Social and Economic Program. These scenarios use different assumptions about international oil and gas prices and economic growth in the rest of the world, and the budget has generally been based on the more conservative scenario. ${ }^{38}$ Revenue and expenditure estimates for the years beyond the forthcoming budget year are not broken down and the budget document does not describe, in quantitative terms, fiscal policies beyond the budget year.

20. Partial information on contingent liabilities and "tax expenditures" is presented together with the budget. ${ }^{39}$ The Budget Code includes government guarantees in the definition of public debt, with the result that the annual budget law sets a ceiling on new guarantees and makes a provision for called guarantees. Other than loan guarantees, the government does not identify any contingent liabilities in the budget. The budget document generally provides the cost estimate of each tax expenditure that is going to change during the budget year. ${ }^{40}$ The government monitors the costs of most existing tax expenditures but this information is usually not reported in detail in the budget.

21. The amount of direct subsidies cannot be inferred from the budget and quasifiscal subsidies carried out by public enterprises are not identified in the budget. The budget appropriates specific transfers to subnational governments to cover a portion of the

${ }^{37}$ For instance, revenue and financing transactions are not separated in the form that would be consistent with presentation under the IMF's GFS.

${ }^{38}$ The 2004 budget was developed in 2003 on the basis of an intermediate oil price scenario.

39 "Tax expenditures" relate to the revenue foregone by provisions in the tax code (for example, from exemptions, deductions, incentives, etc) that allow a tax payer to pay a reduced amount of taxes from the normal taxes that would be applicable for a given tax base.

${ }^{40}$ There are exceptions, such as with the introduction of simplified taxes for small businesses. 
losses of the housing and communal services sector. The full extent of budget subsidies is however, unclear, in part because of the absence of an economic specification of expenditures in the annual budget law. ${ }^{41}$ Payments from budget entities to state unitary enterprises, as well as the allocation of assets and liabilities between them, may also entail subsidies that are not reported in the budget. The budget document also does not contain any statement describing the nature of implicit price-subsidies in the state-owned energy sector.

\section{Regular reports on public debt and debt guarantees of the federal government} are published. The Ministry of Finance releases monthly and quarterly data on foreign debt and guarantees, classified by official creditor and type of debt to private creditors, and on domestic debt and guarantees, classified by debt instrument. The CBR publishes monthly data on general government debt held by non-residents and the foreign investment position held by the institutional sectors. ${ }^{42}$ At the end of each year, the Finance Ministry conducts an inventory of the public debt and reconciles differences. Subnational debt, including the municipalities, is reported on a monthly basis. The quality of subnational debt data could be significantly strengthened because of incomplete reporting. Debt policy is subject to continuous external scrutiny. The budget law establishes ceilings on domestic and foreign debts. Annual programs for domestic and foreign borrowings are approved with the budget. ${ }^{43}$ The government is also required to spell out all types of debt management operations planned for the budget year in the annual budget law. The government made public its medium-term debt management strategy for the first time in 2003, including projections of foreign and domestic debt and debt service until 2008.

\section{Information on government financial assets is compiled by the Ministry of} Finance during budget preparation, but most of this information is treated as confidential. The Ministry of Property Relations maintains an inventory of government assets, including stakes in financial and nonfinancial institutions, but budget materials do not contain this data. The public only has access to the information on government's holdings in joint-stock companies (which generally publish their annual balance sheets) on a case-bycase basis. From the 2004 budget, information on debt owed by foreign states to the Russian Federation is published by country in open annexes to the budget law.

\section{Aggregate statistical information on nonfinancial public enterprises is released}

on a quarterly basis. Goskomstats' reports on the State Sector in the Economy, which cover

\footnotetext{
${ }^{41}$ The budget documentation submitted to the Duma includes a preliminary economic classification of expenditure but final information is not published as part of the annual budget law, following the parliamentary approval of the budget. However, for 2005, the authorities plan to provide an economic classification containing information on the volume of budget subsidies in the materials for the Federal Law "On the Federal Budget."

${ }^{42}$ Report on the international investment position of Russia.

${ }^{43}$ This is required by Article 108 of the Budget Code.
} 
all public enterprises as well as entrepreneurial activities of budget entities, provide statistics on production, financial results, and employment in the state enterprise sector, aggregated by economic sector. ${ }^{44}$ No financial information on public enterprises is published on a regular or comprehensive basis by the government. Line ministries and other State bodies monitor independently the budgets and financial results of state unitary enterprises under their responsibility.

\section{Ex post information on the combined budget position of federal and subnational} governments is published on a monthly basis. Information on the consolidated budget of the general government (including federal extrabudgetary funds) is published on an annual basis. Regional and local governments use budget classifications compatible with federal fiscal reporting. They generally publish information on their individual budgets but the Ministry of Finance does not release information on the combined fiscal position implied by the approved budgets. The Ministry of Finance consolidates budget execution reports of the federal and regional governments. Regional governments provide fiscal reports covering all budgets within their jurisdiction on a monthly and quarterly basis (see Box 3, which describes the good data availability practices followed by the city of St. Petersburg). Monthly data is not always complete, with some reporting lags. For instance, some specific expenditure data is missing and budget estimates are used as a proxy. Quality problems have remained despite strict instructions for submitting monthly budget execution reports. ${ }^{45}$ Quarterly reports include data on accounts payables and receivables. Budget coverage improved following efforts in the last few years to eliminate federal and regional extrabudgetary funds (e.g., the regional road fund was closed off in 2003). Also, each month, the Russian Ministry of Finance releases data on the overall financial position of the consolidated government on its internet web site, while data on the budget of the expanded government (including on extrabudgetary funds) are released yearly, consistent with the IMF Special Data Dissemination Standard (SDDS).

\section{The Budget Code requires the release of all non-confidential information} pertaining to approved budgets and their execution, including issues raised during budget deliberations. ${ }^{46}$ Accordingly, all budget preparation documents are released shortly after they are approved by the federal government, and budget execution reports, including the federal law on the Report on Budget Execution approved by the Duma, are published

\footnotetext{
${ }^{44}$ No individual information obtained in the context of government statistical surveys is disclosed, unless there is written consent of the juridical persons and economic entities that provided the data, in accordance with the federal law No. 24-FZ"on "Information, Information Technology and Information Security" of February $20^{\text {th }}, 1995$ (which is based on the principles of official statistics adopted by the UN in 1994).

45 (Ministry of Finance Order No.122, December 29, 2001).

${ }^{46}$ Article 36 of the Budget Code, on the principle of Glasnost (openness).
} 
with the full revenue and expenditure breakdown. Publication practices in the area of fiscal statistics are broadly in line with the IMF SDDS. Budget execution reports are posted on the Ministry of Finance website, on a monthly and quarterly basis for the federal and subnational governments (see paragraph 25) and generally within a month after the end of the reporting period (except for reports on subnational budgets). Budget execution reports for the federal extrabudgetary funds are released on a quarterly basis. Advance release date calendars are available on the Ministry of Finance website. Budget publication practices are defined by an executive order of the cabinet of ministers and ministerial orders, and tend to be quite stable. There have been no major changes for more than 3 years.

\section{Box 3: Budget Information of the City of St. Petersburg ${ }^{47}$}

The Finance Committee of St. Petersburg has achieved high standards of information availability:

- $\quad$ All government activities are presented in the budget, including revenue and expenditure of entrepreneurial activities of budgetary organizations. The city's regional road funds and fund for infrastructure development are incorporated in the budget.

- $\quad$ Booklets about the approved budget and budget execution are published in both Russian and English. They present budget expenditure using functional, economic, and departmental classifications, and provide comparable revenue and expenditure data for the past 3 years. They present a complete set of macroeconomic indicators and up-to-date information on the structure of the city government. Policy changes are specified. Interbudgetary transactions and their individual purposes are presented. Changes in responsibilities delegated to municipalities are identified.

- $\quad$ Detailed information on the structure of public debt and gross borrowing needs is published. The budget booklet provides data on the yield and maturities of domestic government securities and makes explicit the exchange rate and inflation assumptions underpinning the debt service forecast. Debt management is highly transparent. The Finance committee requires the registration of loans contracted since 2002 by all public enterprises under the city's jurisdiction. There is also a St. Petersburg law on public debt, which puts an explicit ceiling on the ratio of guarantees to own budget revenue (20 percent).

To achieve best international practice, St. Petersburg might consider formulating rolling medium-term budgeting plans on a yearly basis and also developing balance sheets covering all assets and liabilities of the city's enlarged public sector (including state enterprises and state holdings in joint-stock companies).

\section{Open Budget Preparation, Execution, and Reporting}

\section{The annual budget presentation focuses on macroeconomic considerations and on the allocation of resources to broad functional areas and programs. The budget}

\footnotetext{
${ }^{47}$ The city of St. Petersburg enjoys a special status alongside Moscow compared to other cities that provides both cities with the same budgetary powers as regional governments. St. Petersburg is composed of 19 administrative districts and 111 autonomous local self-governments.
} 
process is well established and follows a clear timetable. The budget documentation submitted to the Duma is very comprehensive. ${ }^{48}$ Key macroeconomic and budgetary assumptions are documented and published at regular intervals during the process, and are subject to extensive scrutiny and discussions. Budget appropriations are based on departmental and functional classifications. Neither the functional nor the economic classification is fully consistent with international standards (namely, that of the Government Finance Statistics (GFS) Manual). The lack of consistency principally relates to the third and fourth levels of the functional classification. These levels are not assigned to the top levels of the classification in a clear hierarchical structure and they contain elements of both program and economic classification. Efforts are ongoing to bring the classification up to international standards.

28. The overall balance of the federal government is the main indicator of the fiscal position of the budget, despite the importance of oil revenues. This balance is monitored during the year. The Budget Code does not require oil and nonoil revenues to be separately reported nor is a non-oil balance required to be presented as part of the draft budget documents (see Box 5 for a discussion on the potential merits of the nonoil balance), but an oil Stabilization Fund was established in 2004 to accumulate budget funds in periods with high oil prices, and to be used to finance expenditures in periods with low oil prices. The budget definition of the federal government excludes the "entrepreneurial activities" of the budget organizations. Currently, oil-related government revenues are incorporated in the budget. However, the budget document does not give any consolidated presentation of all oilrelated revenues and (possibly) expenditures. The budgets for the three federal government extrabudgetary funds are presented to the Duma for approval together with other budget documents, but there is no consolidation in the annual budget law of the Federal budget with the extrabudgetary funds.

29. Transfers to sub-national governments are included in the budget, but there is no detailed presentation of their overall financial position. While some aggregate information is available, it is not possible to assess accurately the information for all individual regions because their budgets would not yet have been approved. Despite the close financial relationships between the budgetary organizations and the state enterprise sector, there is no consolidated presentation for the broader public sector, and no information is provided on the state enterprises. ${ }^{49}$

\footnotetext{
${ }^{48}$ The Budget law for 2002 included 32 appendices specifying different dimensions of the Budget. The government provides considerable amounts of additional information to the Duma.

${ }^{49}$ In GFSM2001 terms, the "broader public sector" is defined as a combination of the consolidated general government (inclusive of all federal and regional extrabudgetary funds as well as entrepreneurial activities of budget organizations) with state unitary enterprises and joint stock companies with majority government ownership.
} 
30. Budget forecasts are clearly presented in the budget documents, and the main macroeconomic assumptions are disclosed to the public. The budget document includes a presentation of key macroeconomic assumptions and aggregate budget forecasts. These forecasts are based on macroeconomic models prepared by the Russian Ministry of Economic Development and Trade, The Russian Ministry of Finance and the Central Bank of the Russian Federation. The macroeconomic assumptions and the projections are widely published and intensely discussed, but the details of the models themselves are not made publicly available. In the last few years, budget forecasts have tended to be realistic, with a moderately cautious bias.

31. Concerning the characterization of the approach to fiscal policy formulation, a paper laying out the government's medium-term fiscal policy objectives is annually considered by the government, and is submitted to the State Duma together with the draft budget for the upcoming year. The Budget Code establishes rules for subnational budget deficits, debt, and external borrowings. ${ }^{50}$ Subnational deficits are allowed only to finance capital expenditure and should not exceed a fixed share of these budgets' revenue (15 percent and 10 percent of revenue excluding interbudgetary transfers for regional and local budgets, respectively). ${ }^{51}$ In addition, subnational budget debt should not exceed own budget revenue and new external borrowing of subnational governments should not exceed debt service on external debt (interest and amortization). The ratio of debt service to budget expenditure should not exceed 15 percent. These rules are monitored through reporting requirements on budget execution and procedures for authorizing subnational borrowing. Subnational governments violating these rules lose the right to borrow (except to refinance existing debt) until compliance is restored. ${ }^{52}$ The budget documentation discusses fiscal sustainability in broad terms, but there is no formalized analysis of sustainability. There are no detailed medium-term estimates of revenues and expenditure.

32. The budget documents do not provide a comprehensive listing of government assets and liabilities. The Duma is provided with a list of government financial assets, but this list is confidential.

33. The budget includes cost estimates of major policy initiatives and earmarked programs. The budget does not include a consolidated presentation of the cost of new initiatives relative to the ongoing costs of government. The financial and economic implications of tax initiatives are assessed. The 2004 budget submission included an assessment of losses of budget revenue from the provision of tax concessions.

${ }^{50}$ See Articles 92, 106, 107, and 111 of the Budget Code.

${ }^{51}$ Deficits may exceed these ceilings only by the amount of budgeted property sale proceeds.

${ }^{52}$ If a subnational government also fails to remain current on debt service, its budget is audited and the federal Ministry of Finance gains control over its execution. 
34. There is no detailed analysis of sensitivity of the estimates to changes in economic variables. Some of the main fiscal risks are disclosed with the budget, in particular the risks related to international market prices for energy. The budget documents discuss two scenarios for these parameters. The documents provide no specification of contingent liabilities or uncertainties about the future costs of certain programs. The budget contains a total limit for guarantees that may be issued during the year, but provides only a partial specification of these guarantees. The Budget Code (Articles 8.1 and 8.2) indicates that within the budget there may be two reserve funds--a general reserve limited to 3 percent of total spending and the presidential reserve limited to 1 percent. The general reserve can be used for unforeseen expenditures, such as damage control and restoration after disasters and emergencies. The presidential reserve can be used for unforeseen expenditures as authorized by the President, but not for elections, referenda or mass media coverage of the President's activities.

\section{Objectives of federal earmarked programs are generally announced and} progress is reported against these objectives. Until now, there have been no mechanisms for systematic specification and monitoring of other budget program objectives. For the preparation of the 2004 budget, the MOF has asked the state bodies to submit objectives for their budget programs, and plans to establish a tracking and evaluation mechanism for these objectives.

36. Military expenditures and other security-related expenditures are included in the budget on a more aggregated basis than other expenditures. The transparency of military expenditures has increased in the last few years. A number of budget line items for military and security purposes, in particular related to ordinary operating costs, were declassified in 2002. The government submits additional confidential budget documents to the Duma for the discussion and approval of the classified expenditures, and this information is not made publicly available. The Ministry of Defense owns about 400 unitary enterprises but the number is falling. The Ministry of Defense does not own any joint-stock companies. The government's shares in defense companies are held by the Ministry of Property Relations.

37. Internal control and audit procedures are still under development, and the accounting system is partially capable of generating reports on arrears. The concepts of internal control and budgetary accountability are not yet fully defined and operationalized in Russia. Financial control has traditionally been the responsibility of specialized control bodies within the government, but the control of payments and some commitments is now the responsibility of the Federal Treasury. The main budget execution procedures of the Federal Treasury are described in Box 4. Commitment controls are limited to utility payments, where they have proved to be effective in tracking and avoiding arrears. There are no reports of any significant expenditure arrears at the federal level the last few years, but they still occur in sub-national governments. Government regulations for procurement and employment have been strengthened in recent years, but the application of these rules is still 
somewhat uneven. There is no government-wide modern internal audit function, ${ }^{53}$ and few budget organizations have established modern internal audit procedures. Most still retain traditional control departments.

\section{Box 4. Procedures for Budget Execution}

The Federal Treasury is responsible for execution of the budget. The Treasury covers all financial flows for all federal budget entities, including the "own-revenue accounts." The only significant exception is related to the Ministry of Defense, where about 2 percent of expenditures are handled outside the Treasury, mainly due to the absence of treasury offices in some remote regions. The Treasury also handles budget execution for many regional governments, particularly the ones that receive substantial federal transfers.

After the Budget is approved, the Ministry of Finance prepares a detailed financial plan, providing a departmental and economic breakdown of the budget. The allocation is further detailed by the different state bodies for their subordinate units. This breakdown forms the basis for the Treasury's release of funds during the year, which is done through quarterly and monthly warrants.

The Treasury has a wide network of regional and local offices. Budget units are required to pre-register some types of commitments with the Treasury, in particular for utility payments. The budget units submit their payment orders to these offices, where they are verified against the warrants (and the commitment register when applicable). All payments are made by the regional treasury offices.

The Treasury is working to establish a treasury single account mechanism. So far, all Spending Units' local bank accounts have been closed. Revenues are concentrated in the TSA in the Central Bank in Moscow through at the end of the day zero balanced regional treasury accounts in regional branches of the Central Bank. In most cases, expenditures are being made from regional Treasury accounts in regional Central Bank branches. The next step will be to consolidate funds in a fully-fledged TSA in the Central Bank in Moscow, and have the regional expenditure accounts zero balanced at the end of the day. The Treasury is also working to develop a modern government financial management information system. Procurement of the system is scheduled to take place in 2004 and 2005, with subsequent roll-out across the country over the next 2-3 years.

38. The accounting system is capable of producing comprehensive and accurate inyear reports on the federal government budget outturn. The Treasury submits quarterly accounting reports to the Cabinet. These are also submitted to the Duma for information. The coverage is the same as in the annual budget. The quarterly reports are submitted to the Cabinet within 30 days after the end of the quarter. The Treasury also compiles financial reports from sub-national governments. These are posted on the Ministry of Finance website, but not submitted to the government or the Duma. There is no in-year reporting on the state enterprises or government shareholdings in the private sector available to the public. The accounting reports for the federal government are reconciled with Federal Treasury data and

${ }^{53}$ According to international practices, a modern internal audit function would focus on systems evaluation and verification and on providing advice to the operational units, who themselves would be responsible for internal control. 
are believed to be quite accurate. According to the Treasury, in-year financial reports from subnational governments are often incomplete or inaccurate. Although data on an organizational and economic classification are available within the Treasury, all in-year budget reports primarily present data on a functional basis.

39. Tax Code provisions limiting the use of discretion give the national tax administration some legal protection from interference. Tax administration is the responsibility of a separate ministry, the Ministry of Taxation. This Ministry is a federal executive body, but is involved in tax collection for all levels of government. Tax policy is handled by the Ministry of Finance, the Ministry of Economic Development and Trade and the Ministry of Taxation. A new tax code and a number of amendments to other legislation have significantly reduced the discretionary powers of tax officials.

40. There is no legal requirement for a formal mid-year budget review by the Duma. The Duma receives quarterly account statements for information, and the government may submit budget amendment bills during the year. According to the annual budget law, the government has certain powers to amend budget appropriations without Duma involvement. The rules are quite complicated, but in general the government can shift funds between institutions and programs, whereas shifts between functions require Duma approval. The government has broader powers in the case of emergency situations or when government institutions are restructured. Any increases in the deficit or in the overall expenditure level requires Duma approval. In the last few years, budget amendments have often been presented at the end of the year.

41. The audited final accounts are available within $\mathbf{1 3}$ months of the end of the fiscal year. The government submits the final accounts to the Federal Assembly by the end of August. The Accounting Chamber submits its audit report to the Federal Assembly by January of the following year. The accounts are made publicly available when submitted to the Federal Assembly and are approved by the Federal Assembly as a law.

\section{Assurances of Integrity}

42. Budget data are fairly reliable, but initial projections have an appropriately cautionary bias. The variance between budgeted and actual outturn of main fiscal aggregates is disclosed to the legislature and the public and is usually analyzed and explained in budget amendment proposals. During 2000 - 2002, supplementary budgets were used to raise expenditures at the end of the year. There is no established mechanism for detailed tracking and reporting on the accuracy of macroeconomic projections and detailed budget estimates. Deviations between the annual budget and the actual outcomes are generally related to external factors (in particular oil price and interest rate changes) and to policy changes during the year.

43. Statements of accounting policy are not included in the budget and final accounts documents. The current accounting policies are based on the Budget Code and 
provisions in accounting regulations issued by the Ministry of Finance. The government accounts are based on Treasury records, reconciled with the spending units, and are primarily on a cash basis. In addition, budget organizations keep some accounts in an accrual format. Due to outdated accounting standards, the information value of the budget organization accounts, in particular for asset values, is very limited. The Treasury is currently developing an updated accounting framework that will include consolidation of the currently separated accounting practices in the Treasury and the budget organizations, and facilitate a gradual move to accrual accounting, in accordance with international standards, for the whole general government sector.

44. The processes of accounts reconciliation and fiscal reporting are quite effective. Due to the many entities involved and the high volume of transactions in the Treasury accounting system, reconciliation and control procedures are time-consuming and somewhat cumbersome, but there does not seem to be any major systemic quality problems. The planned introduction of a treasury general ledger system over the next few years will give the Treasury ledger access to individual transaction data throughout the system when required, greatly facilitating reconciliation and quality control.

45. External audit is independent of the executive branch. External audit is governed by Articles 102 and 103 of the Constitution, the Federal law "On the Accounting Chamber of the Russian Federation," and the Budget Code. The Chairman of the Accounting Chamber is appointed by the Duma. The Chamber has extensive powers to control the execution of the budget and the implementation of Duma decisions. The work is based on annual audit plans, as well as on requests from Duma members. Unlike in many other countries, the Chamber plays a substantive role in reviewing the draft budget law before it is discussed by the Duma, and in detailed ex post monitoring of budget execution during the year. The Accounting Chamber submits an annual report to the Duma. It also submits a separate audit report on the final accounts ${ }^{54}$.

46. Strengthening of audit capacity is ongoing. Current audit activities and audit reports have a strong focus on legal and financial compliance. ${ }^{55}$

\section{The legislature may follow up on external audit reports through the normal} political process. The reports of the Accounting Chamber are made available to the public, with the exception of audits of confidential military or security expenditures. The audit

\footnotetext{
54 "The draft federal law on the federal budget and budgets of state extra-budgetary funds and on final versions of reports of the execution of these budgets."

55 The Accounting Chamber plans to put more emphasis on system audits and value-for-money audits, and is taking steps to strengthen the organization in this regard. The interaction with internal control and audit bodies of the government, and the delineation of responsibilities for the different control and audit functions, is another key area of emphasis.
} 
reports are reviewed by the Budget Committee, but no specific follow-up procedures are prescribed.

48. External scrutiny of macroeconomic assumptions is encouraged. The Accounting Chamber provides an assessment of the draft budget, including the macroeconomic assumptions and projections. The budget documents are widely distributed and are subject to extensive scrutiny and discussion from independent research institutions, financial analysts, and journalists.

49. The national statistics office is not given legislative assurance of independence. There is no separate law on Goskomstat, which is a federal executive agency. It is assumed that such a law would contradict the Constitution, which states that the organization of the government agencies is the prerogative of the President. A government resolution ${ }^{56}$ assures the technical independence of the agency. There is an independent scientific and methodological board that supervises the statistical quality of its activities. Goskomstat only produces statistical data. It does not provide any form of estimates or projections. Russia has not formally subscribed to SDDS, but follows all substantive SDDS requirements in the provision of financial statistics.

\section{IMF STAFF COMMENTARY}

50. As the analysis in the preceding sections suggests, Russia has achieved considerable progress in the extent of its fiscal transparency and in the management of its public finances since 1999. With the passage of the Budget Code, Parts I and II of the Tax Code, the law pertaining to powers of different levels of government, and other legislation, as well as subsequent amendments, resolutions and presidential decrees, the legal framework has progressively reformed many aspects of the budget and tax system and intergovernmental relations. It has largely clarified the roles and responsibilities of different levels of government as well as the various stages of the budget approval and execution process. Particularly at the federal government level, budget preparation and execution has become increasingly sophisticated, with a high degree of transparency both in the process and in the amount of information available to the public and Duma at all stages. Macroeconomic policy forecasts are soundly based and open for external scrutiny. The rapid pace of implementation of the Treasury system has dramatically strengthened the execution, control, and monitoring of budget outlays. Comprehensive and reasonably reliable data are available on a timely basis, particularly for the federal government, including data on the now limited number of extrabudgetary funds, both for budget estimates and actuals. Tax policy across the board has been substantially modernized to best practices in industrial countries, and the scope for administrative discretion, particularly in terms of tax collections, significantly reduced. Many QFAs have been removed or narrowed in their impact, but some important ones remain.

${ }^{56}$ Federal resolution No. 85 of February 2, 2001. 
There is reasonable transparency on the nature of Russia's debt obligations. The control and audit process, particularly in terms of the reconciliation of federal expenditure estimates and actuals, is quite rigorous.

51. The Russian authorities recognize that a number of important reforms remain to be undertaken - in narrowing the remaining opaqueness in the boundaries between the general government, the public enterprise sector, and the private sector; in addressing remaining weaknesses in intergovernmental relations; in assuring the stability of fiscal policies, independent of the movement of oil prices; in liberalizing the energy market and further reducing QFAs; in further strengthening the budget formulation and execution process; and in enhancing debt management. Yet there is clear evidence that, in most of these areas, the authorities have a clear sense of direction for needed reform, are deeply engaged in an open and transparent process of strategizing and conceptualizing an appropriate medium-term plan of action, and in many cases, are already engaged in implementing these plans.

52. Russia has attained high standards with respect to several of the main indicators of fiscal management and transparency, recognizing that further work is needed in each sphere. In particular:

- the legal framework specifying the government's role and powers as well as the processes that pertain to the budget and taxation are very detailed and comprehensive in many spheres. One consequence however is that there remain inconsistencies and variant interpretations between past statutes and new ones (e.g., in the sphere of taxation between Part I of the Tax Code and the Foundation Law on the Russian Tax System, or between the Budget Code and the Civil Code, or between the Budget Code and some of the laws pertaining to individual sectors, such as in education). Legislation resolving some of these conflicts would help minimize litigation.

- $\quad$ in the financial sector, the CBR has achieved a significant degree of independence. Nevertheless, transparency would be enhanced by amending the CBR law to include a clear prohibition of direct CBR financing of any government budget deficit; also, the CBR's financial relations with the government would be clarified if the CBR were to both pay interest on government deposits and charge the federal and subnational governments for providing services to the Treasury and social insurance funds. Lingering perceptions in the private sector of a privileged role for Sberbank in its access to resources and in the conduct of its lending policies could be countered by establishing a Supervisory Board that is perceived to be independent of the political interests of the government.

- the increasing availability of information on the budget (at all stages) to the Duma and the public (both in the official newspapers and on the Ministry of Finance website) is impressive. Further progress could be achieved by providing, both in the budget estimates and in execution reports, a clear statement of the fiscal 
accounts of the consolidated general government, reflecting all levels of government and extrabudgetary funds. As described below, this should also take account, at least initially in terms of execution reports, of the revenues and expenditures of own revenue accounts of budgetary organizations. There is also an obvious need to provide data to the general public on the entrepreneurial activities of budget organizations, joint stock companies, and state unitary enterprises, both in terms of their current operations as well as on their debts. Efforts to improve the quality and reliability of data originating from the regions would enable fiscal policies at the general government level to be adjusted more expeditiously. The annual budget document should disclose data on both the government's financial assets and debts, and, as accrual accounts get established, provide balance sheets that take full account of all assets and liabilities. There should also be a discussion of the fiscal risks stemming from contingent liabilities in addition to loan guarantees (such as might arise if claims from an expanded deposit insurance scheme were called or from unfunded pension liabilities). Long-term pension trends could be included in a separate annex to the budget. It should also include a list of outstanding tax expenditures (by tax type and including any concessions for small businesses and special economic zones).

- many aspects of the process by which the budget is prepared, deliberated, executed and monitored are quite impressive. Accountability of state bodies will be further enhanced as current efforts are realized to bring the functional and economic budget classifications into full consistency with international standards. Sensitivity analyses of key budget assumptions and parameters should be highlighted in the budget. Progress in expanding the level of detail provided on the 3-year medium-term budget framework would facilitate consideration in the budget of any consequences of new programs. Introduction of long-term scenarios in a supplement to the budget would heighten awareness of longer-term fiscal risks.

- the treasury system has strengthened the quality of budget implementation and enhanced the amount of the data available for budget monitoring. To facilitate monitoring of budget execution, the expected new Chart of Accounts (on which work is underway) should be based on a GFS-consistent budget classification system, reflect international accounting standards in the public sector (IPSAS), and facilitate a gradual transition to accrual accounting. Implementation of the World Bank-financed Federal Treasury Automated System will further enhance financial management and monitoring.

53. In the view of the staff, further progress on a number of issues would help consolidate and expand the gains in fiscal management and transparency made so far. The highest priority should be placed in the following areas:

- One of the most important priorities for future work must be the sharpening of the borders between the government, public enterprise, and private sectors. Either the extrabudgetary activities of budget organizations should be expeditiously 
privatized, or the gross revenues and expenditures of the roughly 59,000 institutions should be explicitly incorporated in the budget, and their debts revealed, so that there is full accountability to the Duma and public for the effective use of resources. Either approach would reduce the scope for state bodies to finance government activities outside the scrutiny of the public. Privatization would need to be accompanied by explicit budget subsidies or transfers to institutions delivering a blend of commercial and government services. Strict criteria should be established to limit further creation of such entrepreneurial units. Speedy progress must occur in developing legislation that clarifies the legal status of the entrepreneurial activities of budget organizations and which also permits their privatization. Care must be taken concerning the risk of debudgetizing units that carry out significant activities of a governmental nature.

- Similarly, privatization efforts should be accelerated for both the roughly 22,000 state unitary enterprises under the supervision of state bodies as well as the $\mathbf{6 , 0 0 0}$ joint stock companies with majority share holdings by the government. The former in particular operate without the scrutiny and disclosure rules or the accounting standards that are applicable to joint-stock companies in the public sector. There are significant risks that state unitary enterprises may be used to distort government finances, for instance, by enterprises taking on expenditure responsibilities of the budget organizations or by allocating assets to a government organization while recording the related liabilities in the accounts of a state unitary enterprise. Moreover, there is an inherent conflict of interest in both instances. For the unitary enterprises, state bodies directly supervise these entities; for the latter, state bodies typically appoint their own employees to sit on the Board of Directors. As a minimum, greater transparency in the governance structure of these enterprises would entail the appointment of independent, well-qualified Board members or supervisory officials who are not state employees (or at least not employees of the state body to which the enterprise is associated). In particular, government ministers and senior officials should not sit on the corporate boards. Equally important, during the period prior to privatization, there needs to be far greater reporting of the operating accounts and balance sheets of all public enterprises.

- The reform of the system of intergovernmental relations is well underway, with recent legislation and forthcoming legislation on track to delineate more clearly powers and expenditure responsibilities of each level of government, provide stable rules for the assignment of the different tax revenues, and specify the formulae that will govern regional transfers to local governments. But high on the agenda must be the tackling of the sources of remaining unfunded mandates, and resolution on how these will be either financed or their underlying commitments resolved so that expectations are no longer unfulfilled and subnational governments are fully in control of expenditure policies for which they are legally responsible. Greater clarity in financing responsibilities should also be sought by rationalizing expenditure assignments in areas of concurrent involvement. Stability and predictability of tax assignments must also be obtained if regions and municipalities are to take responsibility and plan effectively. As greater autonomy is provided to subnational 
governments, enforcement mechanisms are needed to ensure adherence to the Budget Code and to guard against irresponsible policies. Finally, interbudgetary loans should not be used except for liquidity reasons, in line with the Budget Code.

- Russia is still largely a resource-based economy where about one-third of the budget revenues are related to activities in the oil and gas sector. This high degree of dependence makes the budget particularly vulnerable to changes in oil prices, which have shown large fluctuations in recent years. Best practice in fiscal policy management under such volatile conditions calls for extra caution in managing expenditures, especially at times of high oil prices (see Box 5). The government has demonstrated this awareness in its fiscal policies in recent years, as it has accumulated surpluses to ensure against the risks of a decline in oil prices. To prevent high oil prices from imparting a pro-cyclical impact to fiscal and monetary policies, the overall stance of fiscal policy should more explicitly emphasize the objectives for the non-oil fiscal balance.

Recognizing the budget's vulnerability to oil price fluctuations a Stabilization Fund was established in 2004, building on the previously accumulated financial reserve.

\section{Good practice suggests that decisions on the fund's accumulation or} disbursement of resources should be based on a flexible strategy that takes account of the medium-term budget context and which is fully integrated with both the overall budgetary process and the government's asset and liability management strategy. There should also be full disclosure, regular reporting, and audits of the fund's activities.

\section{Box 5. The Non-oil Balance}

Oil revenues are often volatile and uncertain, in addition to representing a depletion of wealth. These characteristics can render the overall fiscal balance misleading in assessing fiscal policy. The nonoil balance provides a clearer picture of the underlying policy stance, since it removes all oil revenues (and expenditures) from the budget. The nonoil balance may also be a more reliable measure of discretionary fiscal policy than the overall balance, since it is a fiscal variable largely under the control of the authorities. In addition, the nonoil balance provides a measure of fiscal vulnerability (for instance, if expenditures have been increased during a period of rising oil prices, the resulting nonoil deficit may be difficult to finance, or become unsustainable without compensating fiscal adjustment at lower oil prices). Highlighting the nonoil deficit in budget documents may help make the use of oil revenues more transparent, and delineate policy choices more clearly.

- The government has a clear medium-term vision on the liberalization of energy markets, and is in the process of narrowing the extent of cross-subsidization in tariff rates between enterprises and households. To further increase transparency, the government should provide budget estimates on the size of quasi-fiscal subsidies provided through the energy sector, with a detailed description of the methodology underlying such estimates (reflecting assumptions on what would be an appropriate 
market-oriented cost for energy and taking account of likely behavioral adjustments in the demand for energy products). In reviewing budget outcomes, estimates of the ex post subsidy should be provided. The methodological basis for the Federal Energy Commission's recommendations on tariff price adjustments should be in the public domain, as should be the justification for industry investment programs.

54. Also meriting attention, though with less high priority, are the following areas for reform:

- $\quad$ Recent efforts to consolidate external debt management are an important first step. As already recognized by the Russian authorities, emphasis must now be placed on a strengthening and integration of domestic and external debt and cash management, taking account of the relevant tradeoffs and focusing on issues of risk management. Greater clarity will now be required in terms of resolving outstanding institutional issues on the location of responsibility within the Ministry of Finance.

- The external audit process, as managed by the Chamber of Accounts, is thorough and has achieved much in assuring the implementation of the budget. The harder challenge in the future will be to create a results-oriented focus in the audit process. Budget documents should describe expected program results, and procedures should then be established for monitoring, evaluation, and reporting. In streamlining and strengthening the internal audit function, formalistic controls should be reduced and more emphasis put on systems and risk-based controls. A clear separation of control responsibilities between the budget organization (internal control), internal audit, and external audit is essential. A comprehensive statement of accounting policy would also be desirable, clarifying the use of accrual and cash accounts and moving toward internationally acceptable accounting standards for state unitary enterprises and joint-stock companies. Providing for public availability of the macroeconomic models of the Ministry of Economy and CBR would facilitate external scrutiny.

- With regard to the energy sector, over time, the fundamental task remains of improving competition in those elements of the sector for which there would not be a natural monopoly situation, with regulated prices only pertaining to the latter. Explicit targeted budget subsidies should be used to assist preferred consumers (primarily poor households) rather than more general quasi-fiscal energy subsidies. In the design of interbudgetary transfers, incentives should be strengthened to improve the discipline and sufficiency of sub-national budgets to ensure that they remain current on payments for energy supplies. A necessary corollary to such policies is prompt implementation of the housing and communal service reform.

- $\quad$ Finally, the progress made in enhancing transparency in recent years will constitute an important pillar of support for the sustainability of Russia's fiscal stance. However, it is also true that the main reforms that have been implemented in 
recent years have had the benefit of a favorable external situation. It would be important to ensure that these improvements can be sustained in more adverse situations. This suggests the desirability of undertaking stress tests of the mediumterm fiscal framework to assess robustness in the event of unanticipated shocks. 